ARTICLE

DOI: $10.1038 / \mathrm{s} 41467-018-03894-6$

\title{
Gold-catalyzed stereoselective cycloisomerization of allenoic acids for two types of common natural $\gamma$-butyrolactones
}

Jing Zhou ${ }^{1}$, Chunling $\mathrm{Fu}^{1} \&$ Shengming Ma (iD ${ }^{1}$

$\gamma$-(E)-Vinylic and $\gamma$-alkylic $\gamma$-butyrolactones are two different types of lactones existing extensively in animals and plants and many of them show interesting biological activities. Nature makes alkylic $\gamma$-butyrolactones by many different enzymatic lactonization processes. Scientists have been mimicking the natural strategy by developing new catalysts. However, direct and efficient access to $\gamma$ - $(E)$-vinylic $\gamma$-butyrolactones is still extremely limited. Here, we wish to present our modular allene approach, which provides an efficient asymmetric approach to (E)-vinylic $\gamma$-butyrolactones from allenoic acids by identifying a new gold complex as the catalyst. Based on this cycloisomerization strategy, the first syntheses of racemic xestospongiene and xestospongienes $E, F, G$, and $H$ have been realized and the absolute configurations of the chiral centers in xestospongienes $E$ and $F$ have been revised. In addition, by applying a $\mathrm{C}-\mathrm{O}$ bond cleavage-free hydrogenation, the syntheses of naturally occurring $\gamma$-alkylic $\gamma$-lactones, $(R)$-4-tetradecalactone, $(S)$-4-tetradecalactone, $(R)$ - $\gamma$-palmitolactone, and $(R)$-4-decalactone, have also been achieved.

\footnotetext{
${ }^{1}$ Laboratory of Molecular Recognition and Synthesis, Department of Chemistry, Zhejiang University, 310027 Hangzhou, Zhejiang, People's Republic of China. Correspondence and requests for materials should be addressed to S.M. (email: masm@sioc.ac.cn)
} 
$\mathrm{N}$ atural products are a big treasure for human beings, which exhibit rich academic and industrial potentials due to their structural diversity and biological activities. As we know, $\gamma$-butyrolactones with common structures of $\gamma$ - $(E)$ vinylic and alkylic $\gamma$-butyrolactones, $E$-I ${ }^{1-4}$ and $\mathbf{I I}^{5-10}$, exist extensively in nature and many of them have been identified with interesting biological potentials, such as anti-HIV ${ }^{1}$, antifungal $^{2,9}$, cytotoxic ${ }^{3}$, anti-bacterial ${ }^{7}$, anti-proliferative ${ }^{8}$ activ- $^{2}$ ities, etc., featuring applications in pharmacy (Fig. 1). Some of these lactones, especially for aliphatic $\gamma$-butyrolactones, are also common flavor source in plants and food, which involved in several metabolic pathways ${ }^{11}$.

So far, very few highly selective asymmetric synthesis of $E$-Itype $\gamma$-butyrolactones with a trans 1,3 -disubstituted $\mathrm{C}=\mathrm{C}$ bond has been reported ${ }^{12,13}$. The approaches for the synthesis of unique $\gamma$-(2,2-disubstituted or 1-iodo) vinylic $\gamma$-butyrolactones ${ }^{14-18}$ are not applicable for the synthesis of the natural $\gamma$-butyrolactones due to the substrate limitation. It is well reasoned that in the Aucatalyzed enantioseletcive approach the control of $E / Z$ selectivity and enantioselectivity are most likely the challenge when 6-monosubstituted allenoic acids were used (Fig. 2d) ${ }^{14-16}$. We envisioned a Au-catalyzed cycloisomerization ${ }^{19-25}$ of optically active 4,5alkadienoic acids, readily available from terminal alkynes and aldehydes, for the direct access to various natural and non-natural enantioenriched $E$-I-type common $\gamma$-butyrolactones, which could further be easily hydrogenated to provide naturally occurring $\gamma$-alkylic $\gamma$-butyrolactones II (Fig. 2e). The latter was usually prepared via the lactonization (Fig. 2a) ${ }^{26-29}$, Baeyer-Villiger oxidation (Fig. $2 \mathrm{~b})^{30}$, and dihydroxylation-lactonization-elimination (Fig. 2c), etc ${ }^{31-34}$. The challenge for strategy in Fig. $2 \mathrm{e}$ is the efficiency of axial-to-central chirality transfer ${ }^{35-43}$ and the control of $Z / E$ selectivity ( $E$-I vs. $Z$-I, which after hydrogenation would afford the enantiomers of lactones II, respectively, thus, leading to a much lower ee) during the cyclic anti-nucleometalation and the efficiency of the proto demetalation process to deliver the required 1,3-disubstituted $E-\mathrm{C}=\mathrm{C}$ bond finishing the catalytic cycle. Overall it is highly desirable to identify a suitable ligand $\mathbf{L}$ for a much more stable complex I over complex II.

Herein, we present the highly stereoselective cycloisomerization of optically active 5-monosubstituted 4,5-alkadienoic acids affording various non-natural and natural enantioenriched $\gamma$-(E)-alkenyl- $\gamma$-butyrolactones by using $\mathrm{AuCl}(\mathrm{LB}-\mathrm{Phos})$ as the catalyst.

\section{Results}

Synthesis of $\mathrm{AuCl}(\mathrm{LB}-\mathrm{Phos})$. At the beginning, we treated $\left(R_{\mathrm{a}}\right)$ 4,5-tridecadienoic acid $\left(R_{\mathrm{a}}\right)$-5a (for its synthesis from aldehyde and terminal alkyne, see: Supplementary Tables 1 and 2) as the model substrate. After screening of some commonly used gold catalysts such as $\mathrm{AuCl}, \mathrm{AuCl}(\mathrm{IPr}), \mathrm{Au}_{2} \mathrm{Cl}_{2}$ (dppm), $\mathrm{Au}_{2} \mathrm{Cl}_{2}$ (dppm) combined with AgOTs was identified as the first generation catalyst to afford the desired $\gamma$-1(E)-alkenyl $(S)$ - $\gamma$-butyrolactone $(S$, $E)-6 a$ in a quantitative yield with a $E / Z$ selectivity of $93: 7$ and $96 \%$ ee in $\mathrm{CHCl}_{3}$ at room temperature for $3 \mathrm{~h}$ (Table 1, entry 1). For the purpose of improving the $E / Z$ selectivity, we tried to identify a more stereoselective catalyst. Based on our recent development of monophosphine ligands ${ }^{44}$, some of the gold complexes of these ligands have been prepared. $\mathrm{AuCl}(\mathrm{LB}-\mathrm{Phos})$, the structure of which was determined by X-ray single crystal diffraction study (Fig. 3$)^{45}$, is one of them.

Optimization of reaction conditions. With this rather sterically bulky $\mathrm{AuCl}(\mathrm{LB}-\mathrm{Phos})$, gladly, an $E / Z$ selectivity of $97: 3$ with $100 \%$ yield and $97 \%$ ee was observed, indicating that the new catalyst was able to control both the $\mathrm{C}=\mathrm{C}$ stereoselectivity and ensure the efficiency of chirality transfer (Table 1, entry 2 ). Inspired by this result, we explored the effect of solvents: $\mathrm{CH}_{2} \mathrm{Cl}_{2}$ gave a similar a
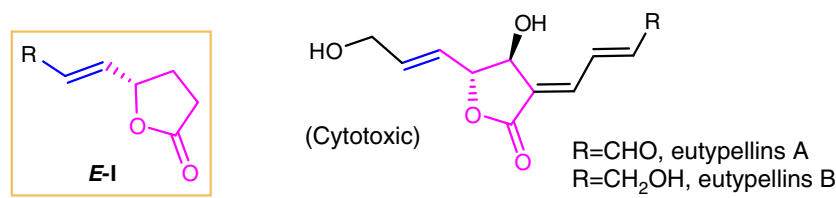

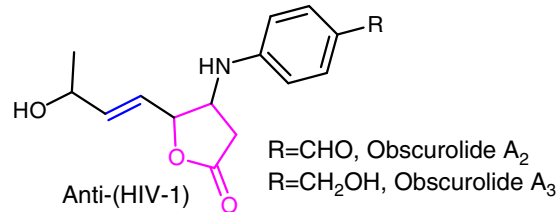

Anti-(HIV-1) $\mathrm{R}=\mathrm{CHO}$, Obscurolide $\mathrm{A}_{2}$
$\mathrm{R}=\mathrm{CH}_{2} \mathrm{OH}$, Obscurolide $\mathrm{A}_{3}$

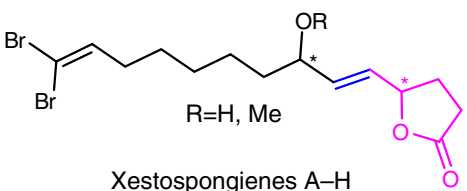
(Isolated from Xestospongia testudinaria)

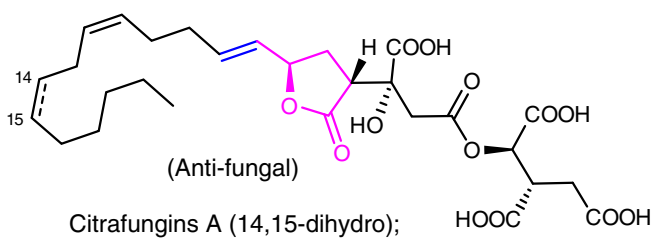

Citrafungins B (14,15-cis-olefin)
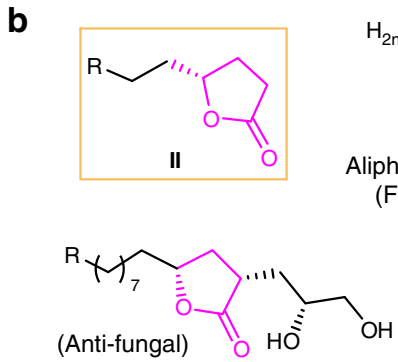

$R=\sqrt[3]{2} \widehat{\mho}$, Rubrenolide

$\mathrm{R}=-\xi \equiv$, Rubrynolide

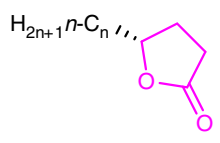

Aliphatic $\gamma$-butyrolactones (Flavor compounds)

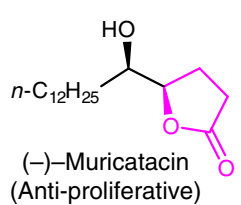

(Anti-proliferative)

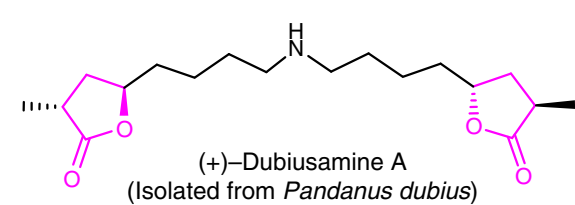

(Isolated from Pandanus dubius)

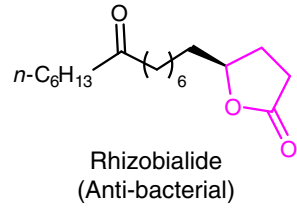

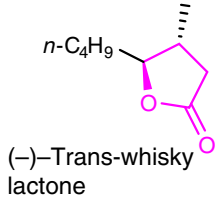

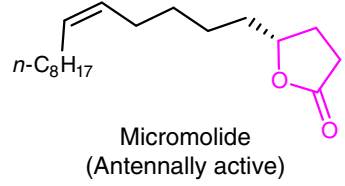

Fig. 1 Representative examples of $\gamma$-(E)-vinylic and $\gamma$-alkylic- $\gamma$-butyrolactones. a Common structure unit and representative examples of $\gamma$-(E)-vinylic $\gamma$ butyrolactones (E-I); b Common structure unit and representative examples of $\gamma$-alkylic $\gamma$-butyrolactones (II) 
a

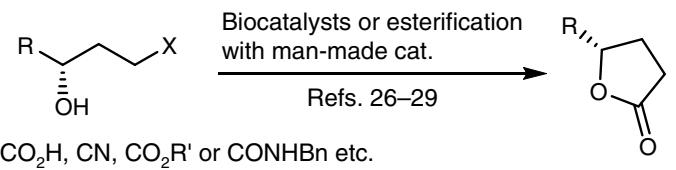

$\mathrm{X}=\mathrm{CO}_{2} \mathrm{H}, \mathrm{CN}, \mathrm{CO}_{2} \mathrm{R}^{\prime}$ or $\mathrm{CONHBn}$ etc.

b

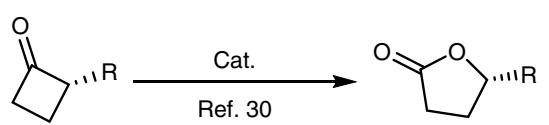

c
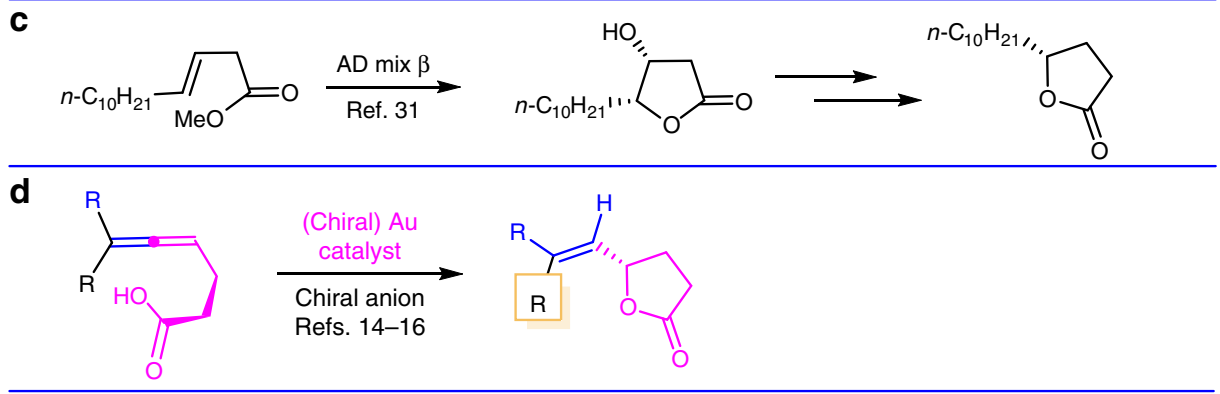

e (This work)
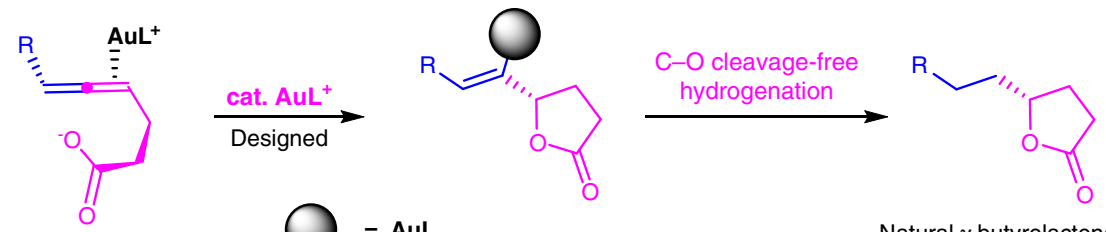

Complex I

AuL

Natural $\gamma$-butyrolactones II

$\downarrow$ Demetal-protonation
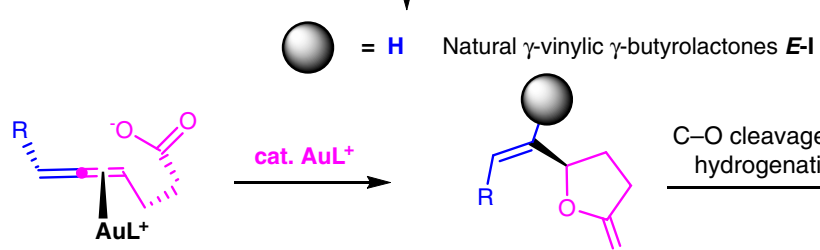

Complex II
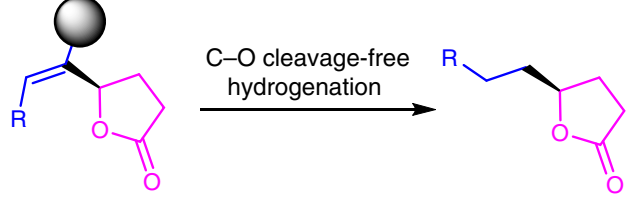

$=$ AuL

Demetal-protonation

ent-II

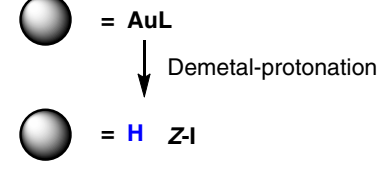

Challenges: E/Z-selectivity: $E$-I vs. Z-I

Efficiency for chirality transfer

Allylic $\mathrm{C}-\mathrm{O}$ bond cleavage leading to racemization

Fig. 2 Known approaches and the designed general protocol to $\gamma$-butyrolactones $E$-I and II. a Nature's enzymatic approaches; $\mathbf{b}$ Baeyer-Villiger oxidation; $\mathbf{c}$ Alkenoate dihydroxylation; d Allene enantioselective approach described in refs. ${ }^{14-16}$. e Au-catalyzed chirality transfer-based asymmetric cyclization of allenoic acids (this work)

$E / Z$ and ee (Table 1, entry 3), while 1,2-DCE led to a rather poor $E / Z$ selectivity of $91: 9$ (Table 1 , entry 4 ); $\mathrm{CH}_{3} \mathrm{NO}_{2}$ showed a better $E$-selectivity of $98: 2$, but a much lower ee of $90 \%$ (Table 1 , entry 6); other solvents such as toluene, dioxane, and $\mathrm{CH}_{3} \mathrm{CN}$ failed to yield any better results even with a prolonged time of $12 \mathrm{~h}$ (Table 1, entries 5, 7-8). In the absence of AgOTs, the expected product 6a was obtained in only $8 \%$ yield with $92 \%$ recovery of $\left(R_{\mathrm{a}}\right)$-5a after $24 \mathrm{~h}$ (Table 1, entry 9), and the lactonization couldn't take place by just using AgOTs (Table 1, entry 10), indicating the significance of the gold-catalysis. Examining the effect of different salts showed the importance of the counter anion: $\mathrm{AgPF}_{6}$ resulted in the same $E / Z$-selectivity but with a lower ee of $92 \%$ (Table 1, entry 11), while other common silver salts such as AgOTf, $\mathrm{AgSbF}_{6}$, and $\mathrm{AgOAc}$, etc. all caused a dropped E/ $Z$ selectivity ranging from $82: 18$ to $93: 7$ (Table 1 , entries 12-16).
Thus, we defined the standard reaction conditions as follows: $5 \mathrm{~mol} \% \mathrm{Au}(\mathrm{LB}-\mathrm{Phos}) \mathrm{Cl} / \mathrm{AgOTs}$ in $\mathrm{CHCl}_{3}$ at $25^{\circ} \mathrm{C}$ for $3 \mathrm{~h}$ (Table 1, entry 2).

Substrate scope. With the optimized reaction conditions in hand, differently substituted 4,5-allenoic acids $\left(R_{\mathrm{a}}\right)-\mathbf{5}$ were treated with AuCl(LB-Phos) to afford $\gamma$-1(E)-alkenyl $(S)$ - $\gamma$-butyrolactones in high yields (93-98\%) with an excellent axial-to-center chirality transfer and $E / Z$-selectivity (up to $>99: 1 E / Z$ ) (Table 2): R could be primary alkyl: $n$-heptyl (6a), $n$-butyl (6b), $n$-undecyl (6c), and phenylethyl $(\mathbf{6 g})$, or branched alkyl: $i-\operatorname{Pr}(\mathbf{6 d})$, and Cy $(\mathbf{6 e})$. The reaction of benzyl-substituted $\left(R_{\mathrm{a}}\right)-\mathbf{5} \mathbf{f}$ should be conducted at $-40{ }^{\circ} \mathrm{C}$ for $6 \mathrm{~h}$ to keep the enantioselectivity due to the observed racemization at $25^{\circ} \mathrm{C}(\mathbf{6 f})$ (compare entry 6 with entry 7 in 


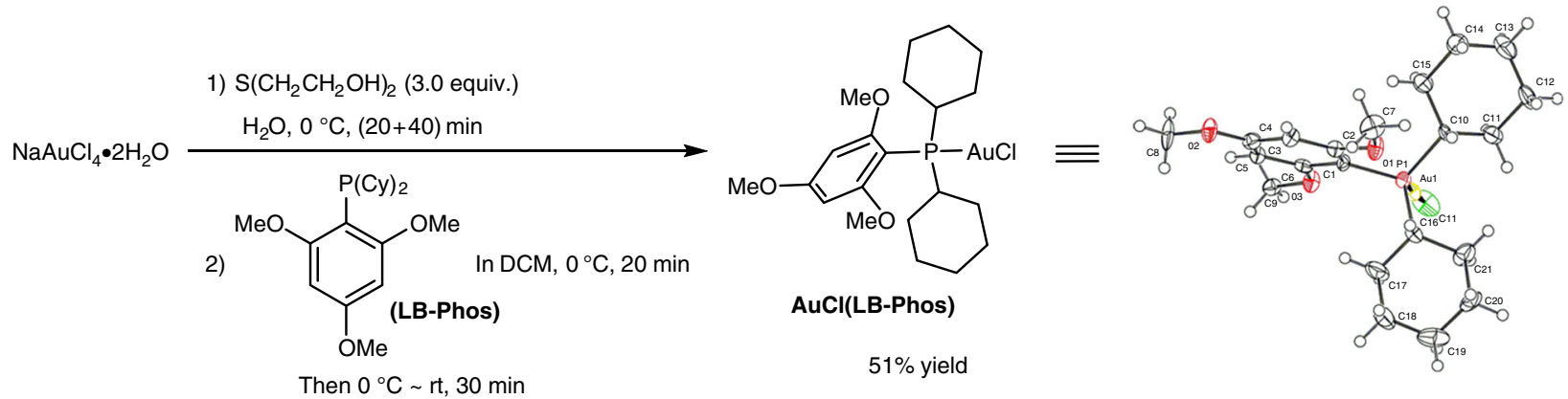

Fig. 3 Complex AuCl(LB-Phos). Synthesis and ORTEP representation of AuCl(LB-Phos)

Table 1 Optimization of the reaction conditions for AuCI(LB-Phos)-catalyzed stereoselective cyclization of 4,5-allenoic acid $\left(R_{\mathrm{a}}\right)-5 \mathrm{a}$

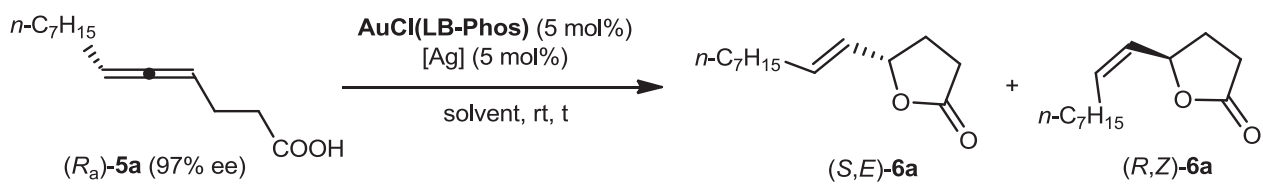

\begin{tabular}{|c|c|c|c|c|c|c|}
\hline \multirow[t]{2}{*}{ Entry } & \multirow[t]{2}{*}{ [Ag] } & \multirow[t]{2}{*}{ solvent } & \multirow[t]{2}{*}{$t(h)$} & \multicolumn{2}{|l|}{$6 a^{a}$} & \multirow[t]{2}{*}{$e e^{b}$ of $(S, E)-6 a(\%)$} \\
\hline & & & & Yield (\%) & $(S, E) /(R, Z)$ & \\
\hline$\overline{1^{c, d}}$ & AgOTs & $\mathrm{CHCl}_{3}$ & 4 & 100 & $93: 7$ & 96 \\
\hline $2^{d}$ & AgOTs & $\mathrm{CHCl}_{3}$ & 3 & 100 & $97: 3$ & 97 \\
\hline 3 & AgOTs & $\mathrm{CH}_{2} \mathrm{Cl}_{2}$ & 3 & 100 & $96: 4$ & 95 \\
\hline 4 & AgOTs & $1,2-$ DCE $^{\mathrm{e}}$ & 3 & 98 & $91: 9$ & 96 \\
\hline 5 & AgOTs & toluene & 12 & 100 & $94: 6$ & 95 \\
\hline 6 & AgOTs & $\mathrm{CH}_{3} \mathrm{NO}_{2}$ & 3 & 99 & $98: 2$ & 90 \\
\hline $9^{f}$ & - & $\mathrm{CHCl}_{3}$ & 24 & 8 & - & - \\
\hline $10^{g}$ & AgOTs & $\mathrm{CHCl}_{3}$ & 24 & 0 & - & - \\
\hline 11 & $\mathrm{AgPF}_{6}$ & $\mathrm{CHCl}_{3}$ & 3 & 100 & $97: 3$ & 92 \\
\hline 12 & AgOMs & $\mathrm{CHCl}_{3}$ & 12 & 99 & $93: 7$ & 97 \\
\hline 13 & AgOTf & $\mathrm{CHCl}_{3}$ & 2 & 100 & $92: 8$ & - \\
\hline 14 & $\mathrm{AgSbF}_{6}$ & $\mathrm{CHCl}_{3}$ & 2 & 96 & $91: 9$ & - \\
\hline
\end{tabular}

Table 2). Functional groups including benzyl group, $\mathrm{C}=\mathrm{C}$, and $\mathrm{C} \equiv \mathrm{C}$ bonds were also tolerated $(\mathbf{6 f}, \mathbf{6 g}, \mathbf{6 h}$, and $\mathbf{6 i})$.

As expected, the enantiomer $(R, E)$-butyrolactone $(\mathbf{6 j})$ could also be prepared from the enantiomer of the starting allene, $\left(S_{\mathrm{a}}\right)$-4,5-dienoic acid $\left(S_{\mathrm{a}}\right)-5 \mathbf{j}$, in a high yield and an excellent E/Z-selectivity (Fig. 4a). After some further optimization (see Supplementary Table 3), a $10 \mathrm{mmol}$ scale reaction with just 1.5 mol\% each of $\mathrm{AuCl}(\mathrm{LB}-\mathrm{Phos})$ and $\mathrm{AgOT}$ in $\mathrm{CHCl}_{3}$ at $-20^{\circ} \mathrm{C}$ for $15 \mathrm{~h}$ was realized, delivering an excellent yield of chiral lactone $(S, E)-6 b$ with $97 \%$ ee and 98:2 E/Z selectivity (Fig. $4 b$ ).

The effect of different gold catalysts. The results of different gold catalysts combined with AgOTs in $\mathrm{CHCl}_{3}$ are listed in
Table 3, which showed that AuCl(LB-Phos) was indeed the best catalyst (Table 3, entry 6).

Synthesis of racemic xestospongiene. Such a strategy should deliver a direct entry to the optically active natural $\gamma$ butyrolactone with common structure $E-\mathbf{I}$ as shown in Fig. 1a. Xestospongienes are a series of brominated polyunsaturated lipids isolated from the Chinese marine sponge Xestospongia testudinaria (shown in Fig. 1a) ${ }^{4}$. No total synthesis has been reported yet. Thus, 7-((tert-butyldimethylsilyl)oxy)heptanal 7 underwent 1,2-addition reaction with ethyl magnesium bromide to yield propargylic alcohol $\mathbf{8}$. Methylation of $\mathbf{8}$ via deprotonation with $\mathrm{NaH}$, followed by quenching with $\mathrm{MeI}$, and subsequent removal 


\section{Table 2 Highly stereoselective synthesis of $(S, E)-6$}

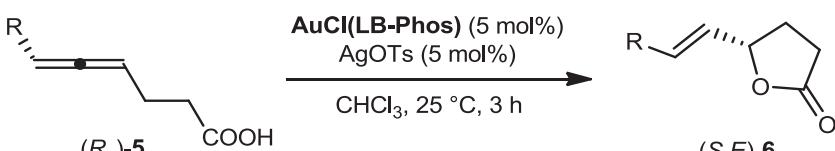

\begin{tabular}{|c|c|c|c|c|c|}
\hline \multirow[t]{2}{*}{ Entry } & \multicolumn{2}{|l|}{$\left(R_{\mathrm{a}}\right)-5$} & \multicolumn{3}{|l|}{$(S, E)-6$} \\
\hline & $\mathbf{R}$ & ee $(\%)$ & Yield $^{\mathrm{a}}(\%)$ & $(S, E) /(R, Z)^{b}$ & $e^{c}(\%)$ \\
\hline $\begin{array}{l}1 \\
2 \\
3^{d} \\
4 \\
5 \\
6 \\
7^{f} \\
8 \\
9 \\
10\end{array}$ & $\begin{array}{l}n-\mathrm{C}_{7} \mathrm{H}_{15}\left(\left(R_{\mathrm{a}}\right)-\mathbf{5 a} \mathbf{a}\right) \\
n-\mathrm{C}_{4} \mathrm{H}_{9}\left(\left(R_{\mathrm{a}}\right)-\mathbf{5 b}\right) \\
n-\mathrm{C}_{11} \mathrm{H}_{23}\left(\left(R_{\mathrm{a}}\right)-\mathbf{5} \mathbf{c}\right) \\
i-\operatorname{Pr}\left(\left(R_{\mathrm{a}}\right)-\mathbf{5 d}\right) \\
\mathrm{Cy}\left(\left(R_{\mathrm{a}}\right)-\mathbf{5 e}\right) \\
\mathrm{Bn}\left(\left(R_{\mathrm{a}}\right)-\mathbf{5} \mathbf{f}\right) \\
\mathrm{Bn}\left(\left(R_{\mathrm{a}}\right)-\mathbf{5} \mathbf{f}\right) \\
\mathrm{BnCH}_{2}\left(\left(R_{\mathrm{a}}\right)-\mathbf{5 g}\right) \\
\mathrm{CH}_{2}=\mathrm{CH}\left(\mathrm{CH}_{2}\right)_{8}\left(\left(R_{\mathrm{a}}\right)-\mathbf{5 h}\right) \\
\mathrm{TBSC}=\mathrm{C}\left(\mathrm{CH}_{2}\right)_{6}\left(\left(R_{\mathrm{a}}\right)-\mathbf{5 i}\right)\end{array}$ & $\begin{array}{l}96 \\
97 \\
97 \\
98 \\
97 \\
96 \\
96 \\
96 \\
96 \\
97\end{array}$ & $\begin{array}{l}96(\mathbf{6 a}) \\
93(\mathbf{6 b}) \\
98(\mathbf{6 c}) \\
94(\mathbf{6 d}) \\
96(\mathbf{6 e}) \\
90(\mathbf{6 f}) \\
95(\mathbf{6 f}) \\
97(\mathbf{6 g}) \\
94(\mathbf{6 h}) \\
96(\mathbf{6 i})\end{array}$ & $\begin{array}{l}98: 2(97: 3) \\
97: 3(96: 4) \\
98: 2(97: 3) \\
99: 1^{\mathrm{e}} \\
99: 1^{\mathrm{e}} \\
95: 5(95: 5) \\
98: 2(97: 3) \\
97: 3(95: 5) \\
>99: 1(97: 3) \\
97: 3(97: 3)\end{array}$ & $\begin{array}{l}96 \\
96 \\
96 \\
98 \\
96 \\
85 \\
97 \\
97 \\
96 \\
97\end{array}$ \\
\hline
\end{tabular}

a
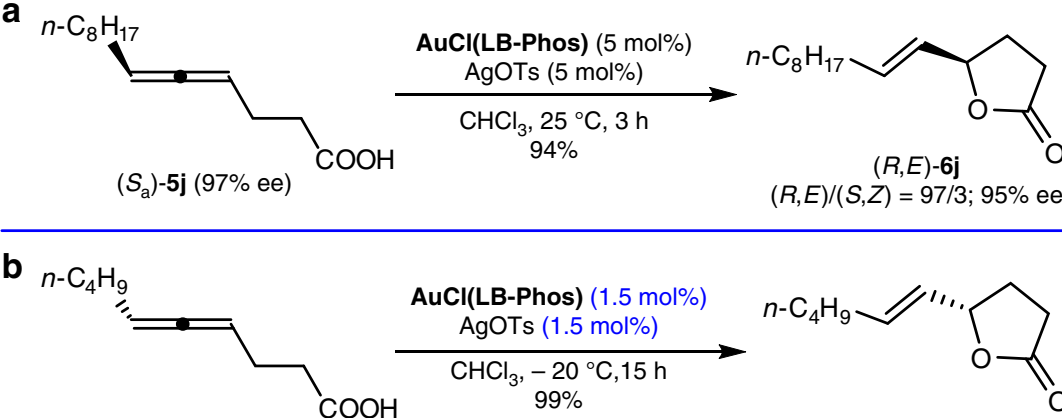

$\left(R_{\mathrm{a}}\right)-5 \mathrm{~b}(98 \%$ ee $)$

$(R, E) /(S, Z)=97 / 3 ; 95 \%$ ee

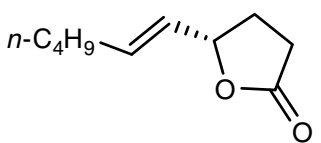

$(S, E)-6 \mathrm{~b}(1.6615 \mathrm{~g})$

$(S, E) /(R, Z)=98 / 2 ; 97 \%$ ee

Fig. 4 Extended scope of Au-catalyzed cycloisomerization reaction. a Synthesis of the enantiomer (R,E)-butyrolactone $\mathbf{6 j}$; $\mathbf{b}$ Gram scale synthesis for $\gamma$ butyrolactone $(S, E)-\mathbf{6 b}$

of the TBS group via acidic hydrolysis yielded the primary alcohol 9 with a terminal C-C triple bond in $88 \%$ yield. Fe(III)-catalyzed aerobic oxidation of 9 afforded aldehyde 10 in $62 \%$ yield ${ }^{46}$. Wittig olefination of the aldehyde functionality in $\mathbf{1 0}$ afforded the terminal alkyne $\mathbf{1} \mathbf{c}^{47}$, which underwent the ATA (allenylation of terminal alkynes) reaction with methyl 4-oxobutanoate $\mathbf{2 k}$ (readily available from $\gamma$-butyrolactone in 2 steps ${ }^{48}$ ) in the presence of diphenylprolinol rac-3a in a sealed tube at $130{ }^{\circ} \mathrm{C}^{49}$ to yield 4,5 -allenoate rac-4ck in $64 \%$ yield. Through hydrolysis, allenoic acid rac-5k was prepared in $96 \%$ yield with a d.r. of 1.07:1, which underwent the gold-catalyzed cycloisomerization with $10 \mathrm{~mol} \%$ catalyst at $-30^{\circ} \mathrm{C}$ for $24 \mathrm{~h}$ (for details, see Supplementary Table 4) to afford rac-xestospongiene in an excellent yield and $E / Z$ ratio of 99:1 (Fig. 5).

Asymmetric synthesis of xestospongienes E-H. It is well known that different stereoisomers of drug molecules may show very distinct biological activities. After methylation, deprotection, aerobic oxidation, and Wittig olefination reaction, $(R)-\mathbf{8}$ and $(S)-\mathbf{8}$ (for their syntheses, see Supplementary Tables 5, 6 and Supplementary Methods ${ }^{50}$ ) were easily converted to terminal propargylic methyl ethers $(R)-\mathbf{1 c}$ and $(S)$-1c, respectively (Fig. 6a, b).

The reaction of $(R)-\mathbf{1} \mathbf{c}, \mathbf{2} \mathbf{k}$, and $(S)$-diphenylprolinol $(S)$-3a in a ratio of $1: 1.5: 1.5$ afforded $\left(R_{\mathrm{a}}, R\right)-\mathbf{4}$ ck as a single stereoisomer in $47 \%$ yield with $>99 \%$ ee and $>99: 1$ d.r. Hydrolysis of $\left(R_{\mathrm{a}}, R\right)-\mathbf{4}$ ck was conducted subsequently by its treatment with $\mathrm{LiOH} \cdot \mathrm{H}_{2} \mathrm{O}$ at $90^{\circ} \mathrm{C}$ for $1.5 \mathrm{~h}$ affording $\left(R_{\mathrm{a}}, R\right)-5 \mathrm{k}$, which was cycloisomerized with $10 \mathrm{~mol} \%$ of $\mathrm{AuCl}(\mathrm{LB}-\mathrm{Phos})$ at $-30^{\circ} \mathrm{C}$ to afford $\left(5 S, 1^{\prime} E, 3^{\prime}\right.$ $R$ )-6k, i.e., xestospongiene $\mathrm{F}$ (reported as xestospongiene $\mathrm{E}^{4}$ ) in $94 \%$ yield with $>99 \%$ ee and $>99: 1$ d.r (Fig. $6 \mathrm{c}$ ). Xestospongienes $\mathrm{G}, \mathrm{H}$, and $\left(5 R, 1^{\prime} E, 3^{\prime} S\right)-6 \mathbf{k}$, i.e., xestospongiene $\mathrm{E}$ (reported as Xestospongiene $\mathrm{F}^{4}$ ) could also be obtained easily with high stereoand enantioselectivity in a similar way by just replacing amino alcohol $(S)$-3a with $(R)$-3a or propargylic alcohol $(R)$-1c with $(S)$ 1c (Fig. 6d-f). Subsequently, gram scale synthesis of xestospongiene $\mathrm{F}$ was easily realized with a high enantiopurity (99\% ee and 98:2 d.r.) (for details, see Supplementary Methods). 


\section{Table 3 The effect of different gold catalyst on the stereoselective cyclization of 4,5-allenoic acid $\left(S_{a}\right)-5 m$}

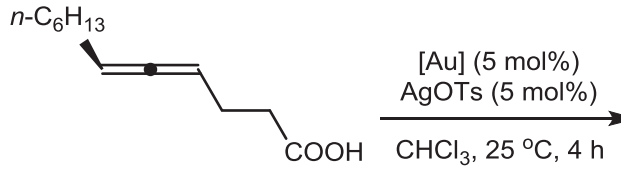

$\left(S_{\mathrm{a}}\right)-\mathbf{5 m}(99 \%$ ee $)$<smiles>O=C1CC[C@@H](/C=C/c2ccccc2)O1</smiles>

$(R, E)-6 \mathrm{~m}$<smiles>CCCCCCCO</smiles>

$(S, Z)-6 m$<smiles>COc1cc(OC)c(P(=O)(O)OC)c(OC)c1</smiles>

LB-Phos<smiles>COC(=O)c1c(OC)cccc1N(C)c1ccccc1</smiles>

Zheda-Phos<smiles>CC(C)Oc1cccc(OC(C)C)c1P(=O)(O)O</smiles>

Gorlos-Phos<smiles></smiles>

$\mathrm{IPr}$

\begin{tabular}{|c|c|c|c|c|}
\hline \multirow[t]{2}{*}{ Entry } & \multirow[t]{2}{*}{ [Au] } & \multicolumn{2}{|l|}{$6 m$} & \multirow[t]{2}{*}{ ee of $(S, E)-6 \mathrm{~m}(\%)^{b}$} \\
\hline & & Yield $^{a}$ & $(R, E) /(S, Z)^{\mathrm{a}}$ & \\
\hline $1^{c}$ & $\mathrm{AuCl}$ & 11 & - & - \\
\hline 2 & $\mathrm{AuCl}(\mathrm{IPr})$ & 100 & $95: 5$ & 96 \\
\hline 4 & $\mathrm{AuCl}\left(t-\mathrm{Bu}_{3} \mathrm{P}\right)$ & 98 & $96.5: 3.5$ & 97 \\
\hline 5 & $\mathrm{AuCl}\left(\mathrm{Ph}_{3} \mathrm{P}\right)$ & 98 & $94: 6$ & 99 \\
\hline 6 & AuCl(LB-Phos) & 100 & $97: 3$ & 99 \\
\hline \multicolumn{5}{|c|}{$\begin{array}{l}\text { AgOTs }(0.01 \mathrm{mmol}),[\mathrm{Au}](0.01 \mathrm{mmol}) \text {, and } \mathrm{CHCl}_{3}(2 \mathrm{~mL}) \text { were stirred at room temperature } \\
\text { mixture was then continuously stirred at } 25^{\circ} \mathrm{C} \text { for } 4 \mathrm{~h} \\
\text { a Determined by }{ }^{1} \mathrm{H} \text { NMR of crude product using } 1,3,5 \text {-trimethylbenzene as internal standa } \\
\text { b Determined by chiral high-performance liquid chromatography (HPLC) analysis } \\
\text { c The reaction was conducted in the absence of } \mathrm{AgOTs} ; 88 \% \text { of }\left(\mathrm{S}_{\mathrm{a}}\right)-5 \mathrm{~m} \text { was recovered } \\
\text { d } 2.5 \text { mol\% } \mathrm{Au}_{2} \mathrm{Cl}_{2}(\mathrm{dppm}) \text { was used } \\
\text { e Reaction time was } 3.75 \mathrm{~h} \\
\text { i } 2 \% \text { recovery of }\left(\mathrm{S}_{\mathrm{a}}\right)-5 \mathrm{~m}\end{array}$} \\
\hline
\end{tabular}

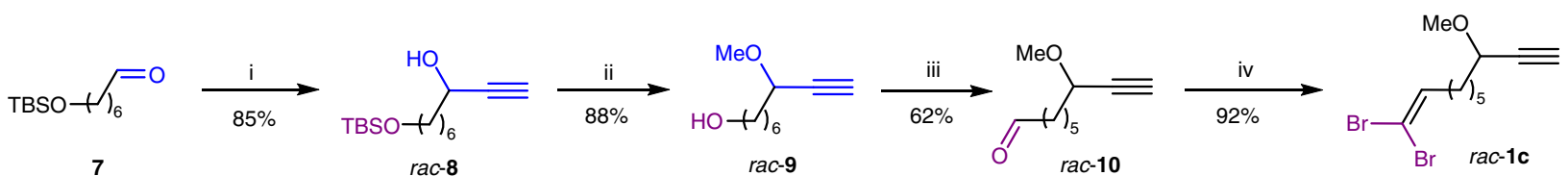
7

rac-8

rac-9 rac-10 $\mathrm{Br}$ rac-1c<smiles>CC(C)(c1ccccc1)C1CCCN1</smiles><smiles>COC(C=CCCC(C)=O)C=CC(Br)=CC(C)=O</smiles><smiles>COC(=O)CC(C=C=CCCC(=O)O)OC</smiles>

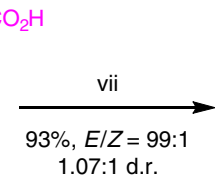
1.07:1 d.r.<smiles>COC(C=CC1CCC(=O)O1)C=C(Br)C(C)(C)C(C)(C)C</smiles>

Fig. 5 First total synthesis of rac-xestospongiene. Reagents and conditions: i. ethynyl-magnesium bromide (1.7 equiv.), THF, rt, $12.5 \mathrm{~h}$; ii. $\mathrm{NaH}$ (1.0 equiv.), $\mathrm{THF}, 0{ }^{\circ} \mathrm{C}, 0.5 \mathrm{~h}$, then $\mathrm{rt}, 0.5 \mathrm{~h}$; then $\mathrm{Mel}\left(1.2 \mathrm{equiv}\right.$.), $0{ }^{\circ} \mathrm{C}, 2 \mathrm{~min}$, then rt, $5 \mathrm{~h}$; then $\mathrm{HCl}($ aq. $3.0 \mathrm{M}), 0{ }^{\circ} \mathrm{C}$, then rt, $1.5 \mathrm{~h}$; iii. $\mathrm{Fe}\left(\mathrm{NO}_{3}\right)_{3} \cdot 9 \mathrm{H}_{2} \mathrm{O}(8 \mathrm{~mol} \%)$, TEMPO (8 mol\%), NaCl (8 mol\%), $\mathrm{O}_{2}$ balloon, $\mathrm{DCM}, 25^{\circ} \mathrm{C}, 12.5 \mathrm{~h}$; iv. $\mathrm{CBr}_{4}\left(1.5\right.$ equiv.), $\mathrm{PPh}_{3}\left(3.0\right.$ equiv.), $\mathrm{DCM}, 0^{\circ} \mathrm{C}, 0.5 \mathrm{~h}$, then $0^{\circ} \mathrm{C} \sim \mathrm{rt}, 1 \mathrm{~h} ; \mathrm{v} . \mathrm{rac}-3 \mathrm{a}$ (1.5 equiv.), methyl 4-oxobutanoate $\mathbf{2 k}$ (1.5 equiv.), $\mathrm{CuBr}_{2}(20 \mathrm{~mol} \%)$, dioxane, $130{ }^{\circ} \mathrm{C}, 17 \mathrm{~h}$; vi. $\mathrm{LiOH} \bullet \mathrm{H}_{2} \mathrm{O}\left(1.5 \mathrm{equiv}\right.$.), $\mathrm{EtOH} / \mathrm{H}_{2} \mathrm{O}=1: 1,90{ }^{\circ} \mathrm{C}, 1.5 \mathrm{~h}$; vii. AuCl(LB-Phos) (10 mol\%), AgOTs (10 mol\%), $\mathrm{CHCl}_{3},-30^{\circ} \mathrm{C}, 24 \mathrm{~h}$

Asymmetric syntheses of naturally occurring $\gamma$-alkylic $\gamma$-lactones. As stated above, aliphatic $\gamma$-butyrolactones are the major aroma components of many industrial fragrances and ingredients in flavors and as food additives ${ }^{11}$, some of which also work as quorum-sensing molecules in vivo ${ }^{51}$. Hydrogenation of the $\mathrm{C}=\mathrm{C}$ bond in (E)-alkenyl $\gamma$-butyrolactones $E$-I would provide an efficient entry to these naturally occurring $\gamma$-alkylic $\gamma$-lactones II listed in Fig. 1b, provided that the cleavage of the allylic $\mathrm{C}-\mathrm{O}$ bond causing racemization to the chiral center under the transition metal catalysis may be avoided. 
a

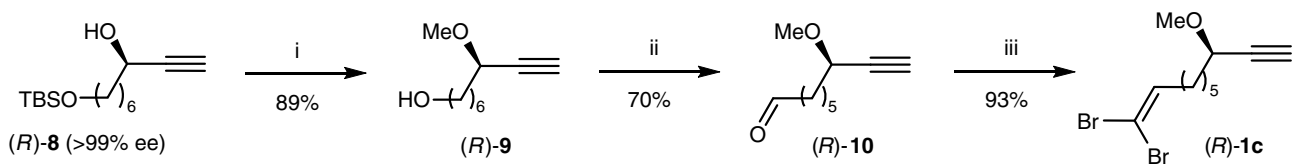

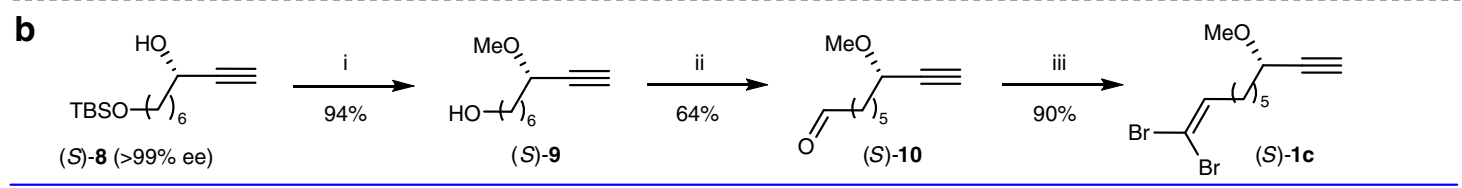

C
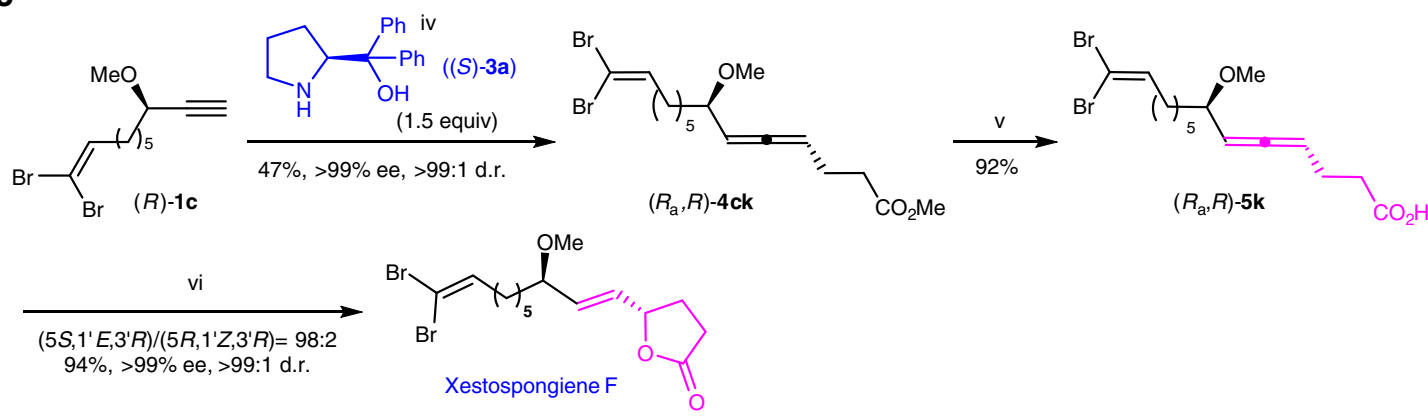

d
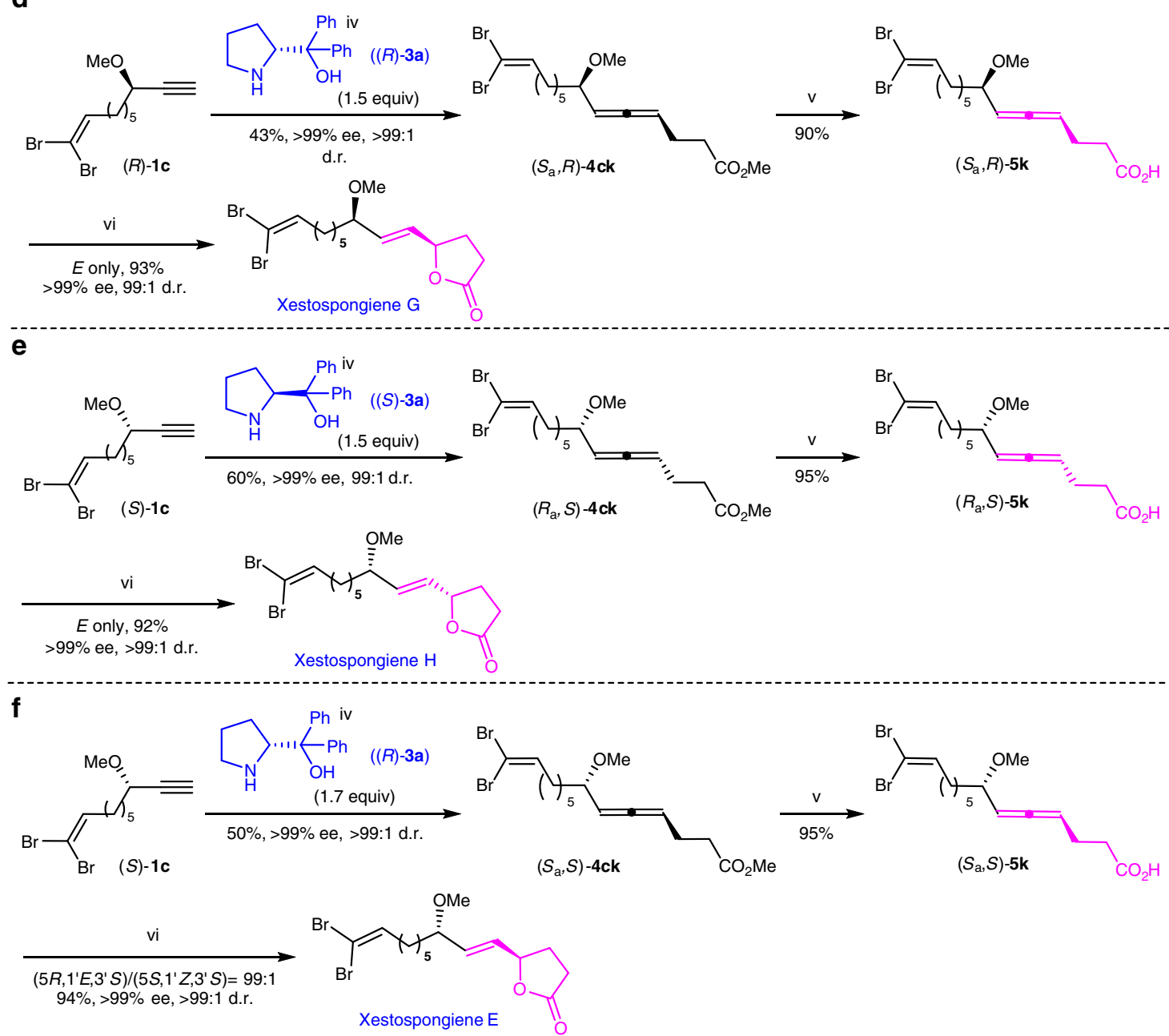

Fig. 6 First total synthesis of xestospongienes E-H. a Synthesis of (R)-1c; $\mathbf{b}$ Synthesis of $(S)$-1c; $\mathbf{c}$ Total synthesis of xestospongiene F; $\mathbf{d}$ Total synthesis of xestospongiene $\mathrm{G}$; e Total synthesis of xestospongiene $\mathrm{H}$; $\mathbf{f}$ Total synthesis of xestospongiene $\mathrm{E}$. Reagents and conditions: $\mathrm{i} . \mathrm{NaH}\left(1.0\right.$ equiv.), $\mathrm{THF}$, $\mathrm{O}{ }^{\circ} \mathrm{C}$ then rt; then $\mathrm{Mel}\left(1.2\right.$ equiv.), $0^{\circ} \mathrm{C} \sim \mathrm{rt}$; then $\mathrm{HCl}$ (aq., $\left.3.0 \mathrm{M}\right), \mathrm{MeOH}$, rt; ii. Fe( $\left.\mathrm{NO}_{3}\right)_{3} \bullet 9 \mathrm{H}_{2} \mathrm{O}(10 \mathrm{~mol} \%), \mathrm{TEMPO}(10 \mathrm{~mol} \%), \mathrm{NaCl}(10 \mathrm{~mol} \%), \mathrm{O}_{2}$ balloon, $\mathrm{DCM}$, rt; iii. $\mathrm{CBr}_{4}$ (1.5 equiv.), $\mathrm{PPh}_{3}$ (3.0 equiv.), $\mathrm{DCM}, \mathrm{O}^{\circ} \mathrm{C}$; iv. methyl 4-oxobutanoate $\mathbf{2 k}$ (1.5-1.7 equiv.), $\mathrm{CuBr}_{2}\left(20 \mathrm{~mol} \%\right.$ ), dioxane, $12 \mathrm{O}^{\circ} \mathrm{C}$; v. $\mathrm{LiOH}^{\circ} \mathrm{H}_{2} \mathrm{O}$ (1.5 equiv.), $\mathrm{EtOH} / \mathrm{H}_{2} \mathrm{O}=1: 1,90^{\circ} \mathrm{C}$; vi. AuCl(LB-Phos) $(10 \mathrm{~mol} \%), \mathrm{AgOTs}(10 \mathrm{~mol} \%), \mathrm{CHCl}_{3},-30^{\circ} \mathrm{C}$ 

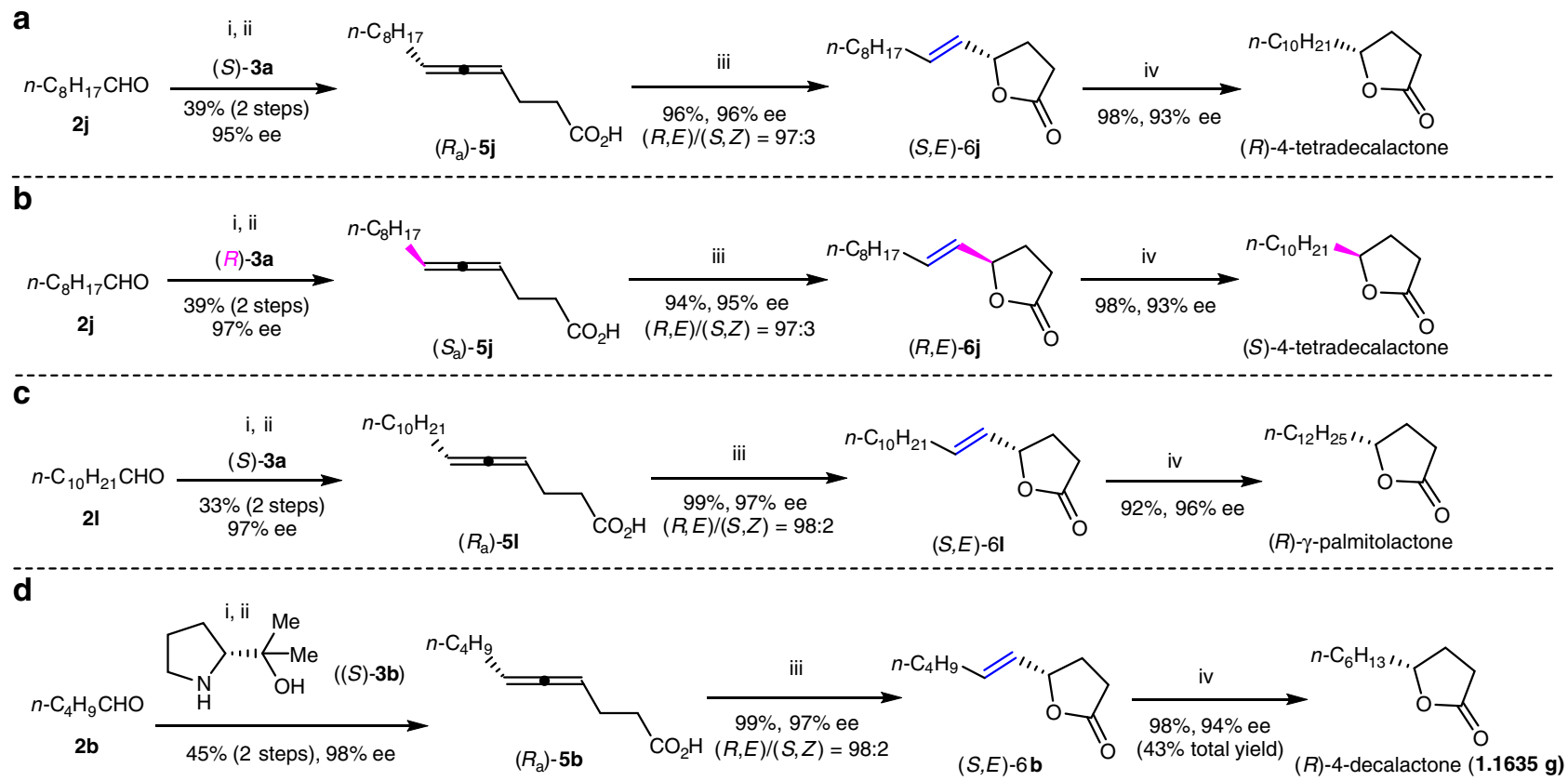

Fig. 7 Synthesis of biologically active aliphatic $\gamma$-butyrolactones. a Synthesis of biologically active $(R)$-4-tetradecalactone; $\mathbf{b}$ Synthesis of biologically active (S)-4-tetradecalactone; c Synthesis of biologically active $(R)$ - $\gamma$-palmitolactone; $\mathbf{d}$ Synthesis of biologically active $(R)$-4-decalactone. Reagents and conditions: i. ethyl pent-4-ynoate $\mathbf{1 b}\left(1.2\right.$ equiv.), $\mathbf{2}$ (1.5 equiv.), $\mathbf{3}$ (1.0 equiv.), $\mathrm{CuBr}_{2}$ (20 mol\%), dioxane, $120^{\circ} \mathrm{C} ; \mathrm{ii} . \mathrm{LiOH} \bullet \mathrm{H}_{2} \mathrm{O}\left(1.5\right.$ equiv.), $\mathrm{EtOH} / \mathrm{H}_{2} \mathrm{O}=1: 1$, $90^{\circ} \mathrm{C}$; iii. AuCl(LB-Phos)/AgOTs (1.5-5 mol\%), $\mathrm{CHCl}_{3}$; iv. Pd/C (2.4-5 mol\%), $\mathrm{H}_{2}$ (25 atm), EtOAc, rt

It has been established that the two enantiomers of $\gamma$-alkylic $\gamma$-butyrolactones made some differences in odor quality and odor intensity ${ }^{11,52,53}$. Thus, we tried to synthesize both $(R)$ and $(S)-\gamma$-lactones by utilizing the current strategy. Starting from asymmetric allenylation of readily available ethyl pent-4-ynoate $\mathbf{1 b}$ with nonanal $\mathbf{2} \mathbf{j}$ in the presence of $(S)$-3a, followed by hydrolysis, 4,5 -allenoic acid $\left(R_{\mathrm{a}}\right)-5 \mathbf{j}$ was afforded in $39 \%$ yield with $95 \%$ ee. Subsequent Au-catalyzed cycloisomerization of $\left(R_{\mathrm{a}}\right)-5 \mathbf{j}$ was executed to yield $\gamma$-butyrolactone bearing a trans $\mathrm{C}=\mathrm{C}$ bond $(S, E)-6 \mathbf{j}$ in $96 \%$ yield with $96 \%$ ee and $97: 3 \mathrm{E} / Z$. (R)-4-tetradecalactone was obtained by hydrogenation of $(S, E)-6 \mathbf{j}$ in the presence of $5 \mathrm{~mol} \% \mathrm{Pd} / \mathrm{C}$ in $98 \%$ yield with $93 \%$ ee (Fig. 7a) $)^{30,31,54,55}$

The enantiomer (S)-4-tetradecalactone was executed by following the same synthetic route just by replacing $(S)$-3a with $(R)-3 \mathbf{a}$ in the step of EATA (enantioselectivi allenylation of terminal alkynes) reaction, giving the desired product with a similar yield and enantioselectivity (Fig. $7 b)^{30,55}$. Similarly, naturally occurring aromatic $(R)-\gamma$-palmitolactone was synthesized in $96 \%$ ee by just using undecanal $\mathbf{2 l}$ as the starting aldehyde in EATA reaction (Fig. $7 \mathrm{c})^{56}$. (R)-4-Decalactone is a sex pheromone of Osmoderma eremite released mainly or exclusively by male beetles ${ }^{57}$, which has also proven to be cytotoxic ${ }^{58,59}$, and synthesized with biocatalysts ${ }^{26,58,59}$ or by other strategies ${ }^{29,53,60}$. Gram scale synthesis of $(R)$-4-decalactone was also realized easily in $43 \%$ total yield for 4 steps with $94 \%$ ee (Fig. $7 d$ ).

\section{Discussion}

A facile strategy for general asymmetric synthesis of two types of common $\gamma$-butyrolactones from readily available common chemicals-terminal alkynes and aldehydes-has been developed by applying the newly identified catalyst, $\mathrm{AuCl}(\mathrm{LB}-\mathrm{Phos})$, with the stereoselectivity of up to $>99: 1 \mathrm{E} / \mathrm{Z}$ and $>99 \%$ ee. The first total syntheses of xestospongienes $\mathrm{E}, \mathrm{F}, \mathrm{G}$, and $\mathrm{H}$ have been realized with high stereoselectivity. In addition, the $\mathrm{C}-\mathrm{O}$ bond cleavagefree hydrogenation led to a general access to naturally occurring $\gamma$-alkyl $\gamma$-butyrolactones, such as (R)-4-tetradecalactone, $(S)$-4- tetradecalactone, $(R)-\gamma$-palmitolactone, and (R)-4-decalactone, efficiently with ee of 93-96\%. Such a modular solution to two different types of optically active $\gamma$-butyrolactones will surely stimulate further interest in the synthetic and bio-potential of these compounds and identifying even better aromas for human life. Further studies on this area are being carried out in our laboratory.

\section{Methods}

General method for cycloisomerization of alkadienoic acids. To a dry Schlenk tube were added AgOTs ( $0.0142 \mathrm{~g}, 0.05 \mathrm{mmol}$, weighed in glove box, $98 \%$ ), $\mathrm{AuCl}$ (LB-Phos) $(0.0299 \mathrm{~g}, 0.05 \mathrm{mmol})$, and $\mathrm{CHCl}_{3}(5 \mathrm{~mL})$ under nitrogen atmosphere sequentially. After stirring for $15 \mathrm{~min},(R)$-trideca-4,5-allenoic acid $\left(R_{\mathrm{a}}\right)-5 \mathrm{a}(0.2108 \mathrm{~g}$, $1 \mathrm{mmol})$ and $\mathrm{CHCl}_{3}(5 \mathrm{~mL})$ were added. After being continuously stirred at $25^{\circ} \mathrm{C}$ for $3 \mathrm{~h}$, the reaction was complete as monitored by thin layer chromatography (TLC). Filtration through a short column of silica gel [eluent: $\mathrm{Et}_{2} \mathrm{O}(20 \mathrm{~mL} \times 3)$ ] and evaporation afforded a crude mixture of $(S, E)-\mathbf{6} \mathbf{a}$ and $(R, Z)-\mathbf{6} \mathbf{a}((S, E) /(R, Z)=$ 97:3, as determined by ${ }^{1} \mathrm{H}$ NMR analysis). Column chromatography on silica gel afforded $(S, E)-6 \mathbf{a}\left(0.2017 \mathrm{~g}, 96 \%,(S, E) /(R, Z)=98: 2\right.$ as determined by ${ }^{1} \mathrm{H}$ NMR analysis) [eluent: petroleum ether $\left(60-90^{\circ} \mathrm{C}\right) /$ ethyl acetate $=15 / 1(400 \mathrm{~mL})$ to $10 / 1$ $(550 \mathrm{~mL})]$ as an oil with pleasant flavor: $96 \%$ ee (HPLC conditions: Chiralcel OJ-H column, $n$-hexane $/ i$-PrOH $=200 / 1,1.0 \mathrm{~mL} / \mathrm{min}, \lambda=214 \mathrm{~nm}, t_{\mathrm{R}}$ (major) $=22.73$ $\left.\min , t_{\mathrm{R}}(\operatorname{minor})=20.86 \mathrm{~min}\right) ;[\alpha]_{\mathrm{D}}{ }^{20}=+29.6\left(c=1.01, \mathrm{CHCl}_{3}\right) ;{ }^{1} \mathrm{H}$ NMR $(300$ $\left.\mathrm{MHz}_{2} \mathrm{CDCl}_{3}\right) \delta 5.81\left(\mathrm{dt}, J_{1}=15.3 \mathrm{~Hz}, J_{2}=7.2 \mathrm{~Hz}, 1 \mathrm{H},=\mathrm{CH}\right), 5.49\left(\mathrm{dd}, J_{1}=15.3\right.$ $\left.\mathrm{Hz}, J_{2}=7.2 \mathrm{~Hz}, 1 \mathrm{H},=\mathrm{CH}\right), 4.90(\mathrm{q}, J=7.2 \mathrm{~Hz}, 1 \mathrm{H}, \mathrm{CH}), 2.61-2.50\left(\mathrm{~m}, 2 \mathrm{H}, \mathrm{CH}_{2}\right)$ 2.46-2.31 (m, $1 \mathrm{H}$, one proton from $\left.\mathrm{CH}_{2}\right), 2.13-1.90\left(\mathrm{~m}, 3 \mathrm{H}, \mathrm{CH}_{2+}\right.$ one proton from $\left.\mathrm{CH}_{2}\right), 1.45-1.18\left(\mathrm{~m}, 10 \mathrm{H}, \mathrm{CH}_{2} \times 5\right), 0.88\left(\mathrm{t}, J=6.6 \mathrm{~Hz}, 3 \mathrm{H}, \mathrm{CH}_{3}\right)$; the following signals are discernible for $(R, Z)-6 \mathrm{a}: \delta 5.72-5.62(\mathrm{~m}, 1 \mathrm{H},=\mathrm{CH}), 5.31-5.21$ $(\mathrm{m}, 1 \mathrm{H}, \mathrm{CH}) ;{ }^{13} \mathrm{C} \mathrm{NMR}\left(75 \mathrm{MHz}, \mathrm{CDCl}_{3}\right) \delta 177.0,135.6,127.2,81.1,32.0,31.6$, $29.0,28.9,28.7,28.64,28.61,22.5,14.0$; IR (neat) $v\left(\mathrm{~cm}^{-1}\right) 2955,2926,2855,1778$, 1673, 1459, 1415, 1378, 1327, 1296, 1216, 1177, 1123, 1010; GC-MS (GC condition: injector: $280^{\circ} \mathrm{C}$; column: DB5 column $30 \mathrm{~m} \times 0.25 \mathrm{~mm}$, temperature programming: $60{ }^{\circ} \mathrm{C}(2 \mathrm{~min}), 20^{\circ} \mathrm{C} / \mathrm{min}$ to $280^{\circ} \mathrm{C}, 280^{\circ} \mathrm{C}(30 \mathrm{~min})$; detector: $\left.280{ }^{\circ} \mathrm{C}\right)(70 \mathrm{ev}, \mathrm{EI})$ $m / z(\%)$ for $(S, E)-6 \mathrm{a}: t_{\mathrm{R}}$ (major) $=5.83 \mathrm{~min}: 210\left(\mathrm{M}^{+}, 2.31\right), 111(100)$; for $(R, Z)$ 6a: $t_{\mathrm{R}}$ (minor) $=5.76 \mathrm{~min}: 210\left(\mathrm{M}^{+}, 0.75\right), 111(100)$. HRMS calcd for $\mathrm{C}_{13} \mathrm{H}_{22} \mathrm{O}_{2}$ $\left[\mathrm{M}^{+}\right]: 210.1620$, found: 210.1624 .

Data availability. All data that support the findings of this study are available in the online version of this paper in the accompanying Supplementary Methods (including experimental procedures, compound characterization data).

The X-ray crystallographic coordinates for structure of AuCl(LB-Phos) reported in this study has been deposited at the Cambridge Crystallographic Data Centre (CCDC), under deposition number CCDC 1558142. This data can be obtained free 
of charge from The Cambridge Crystallographic Data Centre via www.ccdc.cam.ac. uk/data_request/cif.

Received: 9 December 2017 Accepted: 20 March 2018

Published online: 25 April 2018

\section{References}

1. Roggo, B. E. et al. 3-Alkanoyl-5-hydroxymethyl tetronic acid homologues and resistomycin: new inhibitors of HIV-1 protease. J. Antibiot. 47, 136-142 (1994).

2. Singh, S. B. et al. Citrafungins A and B, two new fungal metabolite inhibitors of GGTase I with antifungal activity. Org. Lett. 6, 337-340 (2004).

3. Isaka, M. et al. $\gamma$-Lactones and ent-eudesmane sesquiterpenes from the endophytic fungus eutypella sp. BCC 13199. J. Nat. Prod. 72, 1720-1722 (2009).

4. Jiang, W. et al. Brominated polyunsaturated lipids and their stereochemistry from the Chinese marine sponge Xestospongia testudinaria. Tetrahedron 67, 58-68 (2011)

5. Masuda, M. \& Nishimura, K. Absolute configurations of quercus lactones, $(3 S, 4 R)$ - and $(3 S, 4 S)$-3-methyl-4-octanolide, from oak wood and chiroptical properties of mono-cyclic $\gamma$-lactones. Chem. Lett. 10, 1333-1336 (1981).

6. Cosśe, A. A., Bartelt, R. J., James, D. G. \& Pertroski, R. J. Identification of a female-specific, antennally active volatile compound of the currant stem girdler. J. Chem. Ecol. 27, 1841-1853 (2001).

7. Wei, G.-H. et al. Rhizobialide: A new stearolactone produced by mesorhizobium sp. CCNWGX022, a rhizobial endophyte from glycyrrhiza uralensis. Chem. Biodivers. 4, 893-898 (2007).

8. Popsavin, V. et al. Design, synthesis and antiproliferative activity of two new heteroannelated (-)-muricatacin mimics. Bioorg. Med. Chem. Lett. 18, 5182-5185 (2008).

9. Rodrigues, A. M. S. et al. Search for antifungal compounds from the wood of durable tropical trees. J. Nat. Prod. 73, 1706-1707 (2010).

10. Tan, M. A., Kitajima, M., Kogure, N., Nonato, M. G. \& Takayama, H. Isolation and total syntheses of two new alkaloids, dubiusamines-A, and -B, from Pandanus dubius. Tetrahedron 66, 3353-3359 (2010).

11. Dufosse, L., Latrasse, A. \& Spinnler, H.-E. Importance des lactones dans les arômes alimentaires: structure, distribution, propriétés sensorielles et biosynthèse. Sci. Aliments 14, 17-50 (1994).

12. Brown, H. C., Kulkarni, S. V. \& Racherla, U. S. Chiral synthesis via organoboranes. 39. A facile synthesis of $\gamma$-substituted- $\gamma$-butyrolactones in exceptionally high enantiomeric purity. J. Org. Chem. 59, 365-369 (1994).

13. Grover, H. K., Emmett, M. R. \& Kerr, M. A. $\gamma$-Substituted butanolides from cyclopropane hemimalonates: an expedient synthesis of natural $(R)$-dodecan4-olide. Org. Lett. 15, 4838-4841 (2013).

14. Hamilton, G. L., Kang, E. J., Mba, M. \& Toste, F. D. A powerful chiral counterion strategy for asymmetric transition metal catalysis. Science 317, 496-499 (2007).

15. Handa, S., Lippincott, D. J., Aue, D. H. \& Lipshutz, B. H. Asymmetric goldcatalyzed lactonizations in water at room temperature. Angew. Chem. Int. Ed. 53, 10658-10662 (2014).

16. Shu, X.-Z. et al. Silica-supported cationic gold(I) complexes as heterogeneous catalysts for regio- and enantioselective lactonization reactions. J. Am. Chem. Soc. 137, 7083-7086 (2015).

17. Jiang, X., Fu, C. \& Ma, S. Highly stereoselective iodolactonization of 4,5allenoic acids-an efficient synthesis of 5-(1'-iodo-1'(Z)-alkenyl)-4,5-dihydro2(3H)- furanones. Chem. Eur. J. 14, 9656-9664 (2008).

18. Zhang, X., Fu, C., Yu, Y. \& Ma, S. Stereoselective iodolactonization of 4allenoic acids with efficient chirality transfer: development of a new electrophilic iodination reagent. Chem. Eur. J. 18, 13501-13509 (2012).

19. Hashmi, A. S. K., Schwarz, L., Choi, J.-H. \& Frost, T. M. A new gold-catalyzed C-C bond frmation. Angew. Chem. Int. Ed. 39, 2285-2288 (2000).

20. Hashmi, A. S. K., Frost, T. M. \& Bats, J. W. Highly selective gold-catalyzed arene synthesis. J. Am. Chem. Soc. 122, 11553-11554 (2000).

21. Fürstner, A. \& Davies, P. W. Catalytic carbophilic activation: catalysis by platinumand gold $\pi$ acids. Angew. Chem. Int. Ed. 46, 3410-3449 (2007).

22. Krause, N. \& Winter, C. Gold-catalyzed nucleophilic cyclization of functionalized allenes: a powerful access to carbo- and heterocycles. Chem. Rev. 111, 1994-2009 (2011).

23. Yang, W. \& Hashmi, A. S. K. Mechanistic insights into the gold chemistry of allenes. Chem. Soc. Rev. 43, 2941-2955 (2014).

24. Dorel, R. \& Echavarren, A. M. Gold(I)-catalyzed activation of alkynes for the construction of molecular complexity. Chem. Rev. 115, 9028-9072 (2015).

25. Day, D. P. \& Chan, P. W. H. Gold-catalyzed cycloisomerizations of $1, n$-diyne carbonates and esters. Adv. Synth. Catal. 358, 1368-1384 (2016).
26. Cardillo, R., Fronza, G., Fuganti, C., Gsselli, P. \& Nepoti, V. On the mode of conversion of racemic, $\mathrm{C}_{14}-\mathrm{C}_{19}, \gamma$-hydroxy alkene fatty acids into $\mathrm{C}_{7}-\mathrm{C}_{11}$, optically active $\gamma$ - and $\delta$-lactones in cladosporium suaveolens. J. Org. Chem. $\mathbf{5 4}$ 4979-4980 (1989).

27. Huffer, M. \& Schreier, P. Lipase-catalyzed transesterification in organic solvents: preparation and enantiodifferentiation of optically enriched 4(5)-alkylated 1,4(1,5)-olides. Tetrahedron 2, 1157-1164 (1991).

28. Taylor, S. K., Chmiel, N. H., Simons, L. J. \& Vyvyan, J. R. J. Conversion of hydroxy nitriles to lactones using rhodococcus whole cells. J. Org. Chem. 61, 9084-9085 (1996)

29. Matsumura, Y., Endo, T., Chiba, M., Fukawa, H. \& Terao, Y. Facile synthesis of optically active $\gamma$-lactones via lipase-catalyzed reaction of 4-substitued 4-hydroxybutyamides. Chem. Pharm. Bull. 48, 304-305 (2000).

30. Krief, A., Ronvaux, A. \& Tuch, A. Catalytic enantioselective synthesis of 2 -alkylcyclobutanones and 4 -alkyl- $\gamma$-butyrolactones from alkylidenecyclopropanes and the sharpless AD-mix reagent. Bull. Soc. Chim. Belg. 106, 699-702 (1997).

31. Harcken, C. \& Brückner, R. Synthesis of optically active butenolides and $\gamma$-lactones by the sharpless asymmetric dihydroxylation of $\beta, \gamma$-unsaturated carboxylic esters. Angew. Chem. Int. Ed. Engl. 36, 2750-2752 (1997).

32. Fukuzawa, S., Seki, K., Tatsuzawa, M. \& Mutoh, K. A facile synthesis of chiral $\gamma$-butyrolactones in extremely high enantioselectivity mediated by samarium (II) iodide. J. Am. Chem. Soc. 119, 1482-1483 (1997).

33. Movassaghi, M. \& Jacobsen, E. N. A direct method for the conversion of terminal epoxides into $\gamma$-butanolides. J. Am. Chem. Soc. 124, 2456-2457 (2002).

34. Whitehead, D. C., Yousefi, R., Jaganathan, A. \& Borhan, B. An organocatalytic asymmetric chlorolactonization. J. Am. Chem. Soc. 132, 3299-3300 (2010).

35. Bongers, N. \& Krause, N. Golden opportunities in stereoselective catalysis. Angew. Chem. Int. Ed. 47, 2178-2181 (2008).

36. Patil, N. T. Chirality transfer and memory of chirality in gold-catalyzed reactions. Chem. Asian J. 7, 2186-2194 (2012).

37. Neff, R. K. \& Frantz, D. E. Recent applications of chiral allenes in axial-tocentral chirality transfer reactions. Tetrahedron 71, 7-18 (2015).

38. Zhang, Z. et al. Highly active $\mathrm{Au}(\mathrm{I})$ catalyst for the intramolecular exo-hydrofunctionalization of allenes with carbon, nitrogen, and oxygen nucleophiles. J. Am. Chem. Soc. 128, 9066-9073 (2006).

39. Liu, Z., Wasmuth, A. S. \& Nelson, S. G. Au(I)-catalyzed annulation of enantioenriched allenes in the enantioselective total synthesis of (-)-rhazinilam. J. Am. Chem. Soc. 128, 10352-10353 (2006).

40. Gandon, V., Lemière, G., Hours, A., Fensterbank, L. \& Malacria, M. The role of bent acyclic allene gold complexes in axis-to-center chirality transfers. Angew. Chem. Int. Ed. 47, 7534-7538 (2008).

41. Winter, C. \& Krause, N. Structural diversity through gold catalysis: stereoselective synthesis of $\mathrm{N}$-hydroxypyrrolines, dihydroisoxazoles, and dihydro-1,2-oxazines. Angew. Chem. Int. Ed. 48, 6339-6342 (2009).

42. Rao, W., Susanti, D. \& Chan, P. W. H. Gold-catalyzed tandem 1,3-Migration/ [2+2] cycloaddition of 1,7-enyne benzoates to azabicyclo[4.2.0]oct-5-enes. J. Am. Chem. Soc. 133, 15248-15251 (2011).

43. Cox, N., Uehling, M. R., Haelsig, K. T. \& Lalic, G. Catalytic asymmetric synthesis of cyclic ethers containing an $\alpha$-tetrasubstituted stereocenter. Angew. Chem. Int. Ed. 52, 4878-4882 (2013).

44. Lü, B., Fu, C. \& Ma, S. Application of a readily available and air stable monophosphine $\mathrm{HBF}_{4}$ salt for the Suzuki coupling reaction of aryl or 1-alkenyl chlorides. Tetrahedron Lett. 51, 1284-1286 (2010).

45. Eggleston, D. S. \& Chodosh, D. F. Synthesis and X-ray crystal structure determination of two pseudopolymorphic forms of $\mu$-[1,2-bis (diphenylphosphino)ethane] bis [chlorogold(I)]: a Digold(I) DNA binder. Inorg. Chim. Acta 108, 221-226 (1985).

46. Ma, S. et al. Development of a general and practical iron nitrate/TEMPOcatalyzed aerobic oxidation of alcohols to aldehydes/ketones: catalysis with table salt. Adv. Synth. Catal. 353, 1005-1017 (2011).

47. Desai, N. B., Mckelvie, N. \& Ramirez, F. A new synthesis of 1,1dibromoölefins via phosphine-dibromomethylenes. The reaction of triphenylphosphine with carbon tetrabromide. J. Am. Chem. Soc. 84, $1745-1747$ (1962).

48. Gannett, P. M. et al. The capsaicinoids: their separation, synthesis, and mutagenicity. J. Org. Chem. 53, 1064-1071 (1988).

49. Huang, $\mathrm{X}$. et al. General $\mathrm{CuBr}_{2}$-catalyzed highly enantioselective approach for optically active allenols from terminal alkynols. Chem. Commun. 51, 6956-6959 (2015).

50. Xu, D., Li, Z. \& Ma, S. Novozym-435-catalyzed enzymatic separation of racemic propargylic alcohols. A facile route to optically active terminal aryl propargylic alcohols. Tetrahedron Lett. 44, 6343-6346 (2003).

51. Safari, M., Amache, R., Esmaeilishirazifard, E. \& Keshavarz, T. Microbial metabolism of quorum-sensing molecules acyl-homoserine lactones, $\gamma$-heptalactone and other lactones. Appl. Microbiol. Biotechnol. 98, 3401-3412 (2014). 
52. Mosandl, A. \& Günther, C. Stereoisomeric flavor compounds. 20. Structure and properties of gamma-lactone enantiomers. J. Agric. Food Chem. 37, 413-418 (1989).

53. Cooke, R. C. et al. Odor detection thresholds and enantiomeric distributions of several 4-alkyl substituted $\gamma$-lactones in Australian red wine. J. Agric. Food Chem. 57, 2462-2467 (2009).

54. Thijs, L. \& Zwanenburg, B. Rubrenolide, total synthesis and revision of its reported stereochemical structure. Tetrahedron 60, 5237-5252 (2004).

55. Doolittle, R. E., Tumlinson, J. H., Proveaux, A. T. \& Heath, R. R. Synthesis of the sex pheromone of the Japanese beetle. J. Chem. Ecol. 6, 473-485 (1980).

56. Leal, W. S., Kuwahara, S., Ono, M. \& Kubota, S. (R,Z)-7,15-Hexadecadien-4olide, sex pheromone of the yellowish elongate chafer, Heptophylla picea. Bioorg. Med. Chem. 4, 315-321 (1996).

57. Larsson, M. C., Hedin, J., Svensson, G. P., Tolasch, T. \& Francke, W. Characteristic odor of osmoderma eremita identified as a male-released pheromone. J. Chem. Ecol. 29, 575-587 (2003).

58. Feron, G. et al. Production, identification, and toxicity of $\gamma$-decalactone and 4hydroxydecanoic acid from sporidiobolus spp. Appl. Environ. Microbiol. 62, 2826-2831 (1996)

59. Boratyński, F., Dancewicz, K., Paprocka, M., Gabry, B. \& Wawrzeńczyk, C. Chemo-enzymatic synthesis of optically active $\gamma$ - and $\delta$-decalactones and their effect on aphid probing, feeding and settling behavior. PLOS ONE 11, e0146160 (2016).

60. Kula, J., Sikora, M., Sadowska, H. \& Piwowarski, J. Short synthetic route to the enantiomerically pure $(R)-(+)-\gamma$-dccalactone. Tetrahedron $52,11321-11324$ (1996).

\section{Acknowledgements}

Financial support from the National Natural Science Foundation of China (21572202 and 21690063) is greatly appreciated. Shengming Ma is a Qiu Shi Adjunct Professor at Zhejiang University. We thank Mr Haoyang Wang and Mrs Fang Zhang for assistance with ESI-MS, and we thank Yifan Cui in our group for reproducing the results: $(S, E)-\mathbf{6 h}$, $\left(5 R, 1^{\prime} E, 3^{\prime} S\right)-\mathbf{6 k}$, and $(S, E)-6 \mathbf{l}$.

\section{Author contributions}

S.M. directed the research and developed the concept of the reaction with J.Z., who also performed the experiments and prepared the Supplementary Methods. J.Z., C.F., and S. M. checked the experimental data. J.Z. and S.M. wrote the manuscript with contributions from the other authors.

\section{Additional information}

Supplementary Information accompanies this paper at https://doi.org/10.1038/s41467018-03894-6.

Competing interests: The authors declare no competing interests.

Reprints and permission information is available online at http://npg.nature.com/ reprintsandpermissions/

Publisher's note: Springer Nature remains neutral with regard to jurisdictional claims in published maps and institutional affiliations.

\section{(c) (P)}

Open Access This article is licensed under a Creative Commons Attribution 4.0 International License, which permits use, sharing, adaptation, distribution and reproduction in any medium or format, as long as you give appropriate credit to the original author(s) and the source, provide a link to the Creative Commons license, and indicate if changes were made. The images or other third party material in this article are included in the article's Creative Commons license, unless indicated otherwise in a credit line to the material. If material is not included in the article's Creative Commons license and your intended use is not permitted by statutory regulation or exceeds the permitted use, you will need to obtain permission directly from the copyright holder. To view a copy of this license, visit http://creativecommons.org/ licenses/by/4.0/.

(c) The Author(s) 2018 